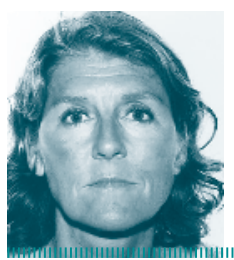

Carina S. Alm, Nasjonalforeningen for folkehelsen

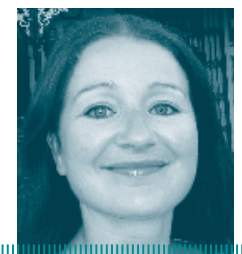

Nicole Warmbrodt, Preventiv kardiologi, avdeling for forebyggende medisin Oslo Universitetssyket Ullevà
Tor Ole Klemsdal, Preventiv kardiologi, avdeling for forebyggende medisin Oslo Universitetssykehus, Ullevål

\title{
Kan forebygge tidlig død
}

\author{
Enkle tiltak gjør det mulig å kartlegge risikofaktorer for hjerte- og karsykdom.
}

$\mathbf{V}$ erdens helseorganisasjon har anslått at 80 prosent av all tidlig (menn $<55$ år og kvinner $<65$ år) hjerte- og karsykdom og 90 prosent av all diabetes type 2 kan forhindres ved å være røykfri, spise sunt og være i jevnlig fysisk aktivitet (1). I Norge som $i$ andre vestlige land har det vært en dramatisk reduksjon i dødsfall som følge av hjerte- og karsykdom de siste 40 årene, hvor endret risikofaktornivå $\mathrm{i}$ befolkningen har vært den viktigste faktoren $(2,3,4)$.

Til tross for de generelt gunstige trender i risikofaktornivå, er en ikke ubetydelig andel av befolkningen ennå belastet med dagligrøyking og ugunstige nivåer av lipider, blodtrykk og glukose, samtidig som andelen med helseskadelig overvekt og diabetes er økende (5). For å sikre videre nedgang i dødelighet av hjerte- og karsykdommer, betyr det mye at man kan identifisere og påvirke risikogrupper i befolkningen som ikke så lett fanges opp av helsevesenet.

\section{Prosjektet}

I dette prosjektet ønsket vi å studere om sykepleiere med oppsøkende virksomhet på et utvalg av arbeidsplasser og offentlige samlings-

\section{Hovedbudskap}

Identifisering av høyrisikoindivider for hjerte- og karsykdom er mulig ved lavterskeltilbud i lokalmiljøet. Kjennskap til egne risikofaktorer var lav i studiepopulasjonen. Frivillige organisasjoner kan ha en rolle i det forebyggende arbeidet.

\section{Søkeord}

Les mer og finn litteraturhenvisninger på våre nettsider. > Hjerte- og karsykdom \Blodtrykk > Risikofaktor Kartlegging plasser, som frivilligsentraler og kjøpesentre, kunne være en måte å fange opp personer med forhøyet risiko for hjerte- og karsykdom. Den oppsøkende screeningen ble utført i regi av Nasjonalforeningen for folkehelsen, i et samarbeid mellom ansatte sykepleiere på Nasjonalforeningens Hjertelinje og organisasjonens lokallag. Kartleggingen besto av kolesterol-, blodsukker- og blodtrykksmåling, to spørreskjema og en samtale om risikofaktorer.

\section{Metode}

Nasjonalforeningens lokallag ble forespurt via organisasjonens fylkeskontor. Lag fra fire fylker; Østfold, Rogaland, Hedmark og Oppland, ønsket å delta i prosjektet. I Oslo rekrutterte vi deltakere via e-posthenvendelse til personalansvarlig på aktuell arbeidsplass. Nasjonalforeningens lokallag fikk i oppgave å skaffe lokale og annonsere arrangementet i lokalmiljøet. Noen steder valgte man i stedet å invitere seg til en lokal arbeidsplass. Deltakelse var gratis. Sykepleiere fra Hjertelinjen møtte opp med blodprøvetakingsutstyr, blodtrykksapparat og spørreskjema. Det ble oppfordret til å møte fastende, men dette var ikke et krav. Alle som møtte fikk delta. Lokallagsmedlemmene bisto med å dele ut samtykkeskjema, spørreskjema, holde orden i køen og servere noe å spise og drikke etterpå.

Det ble tatt kapillær blodprøve av totalkolesterol og triglyserider. Blodtrykket ble målt sittende etter noen minutters hvile. Hvis blodtrykket var > 140/90 ble det kontrollert en gang til og det laveste trykket ble registrert. Livvidden ble målt mellom hoftebein og nedre del av ribbein etter lett utpust og utenpå t-skjorte eller skjorte. Vekten ble målt uten yttertøy og sko.

\section{Spørreskjema}

På samtykkeskjema beskrev vi prosjektet og spurte om lov til å kontakte deltakeren med et nytt spørreskjema i etterkant. Det første spørreskjemaet ble utfylt mens deltakeren ventet på å få komme inn til sykepleier. Det inneholdt spørsmål om deltakeren tidligere hadde målt blodtrykk, kolesterol eller blodtrykk og om man husket verdien. Det ble også spurt om familiehistorie i forhold til hjerte- og karsykdom, røykevaner, fysisk aktivitet, pågående behandling for forhøyet kolesterol eller blodtrykk og hvorvidt personene hadde diabetes.

Det andre spørreskjemaet som ble sendt til deltakerne etter fire til seks måneder, inneholdt spørsmål om de var fornøyde med helseundersøkelsen de hadde deltatt i og om undersøkelsen hadde bidratt til at de spiste sunnere eller mosjonerte mer enn før. Det ble i tillegg spurt om de husket egen kolesterolverdi og om de hadde fulgt et eventuelt råd om å gå til legen.

Vi spurte også om hva deltakeren trodde var årsaken til at folk ikke går til lege for helsesjekk og hva som hadde vært deres egen motivasjon for å møte. Til sist spurte vi om de mente at det burde innføres et slikt helsetilbud for alle over 30 år. Vi ba dem også om å oppgi egen utdanning og hvorvidt de var i jobb eller ikke.

\section{Resultater}

Til sammen 862 personer deltok i kartleggingen, og hos 857 av disse ble det innhentet spørreskjema. Spørreskjema nummer to ble sendt ut til de 857 deltakerne etter fire til seks måneder, og av dem fikk vi svar fra 448 (52 prosent). Gjennomsnittlig alder for de 857 deltakerne var 50 (SD +- 11) år og 54,5 prosent var menn. Av deltakerne var 25,5 prosent røykere, 31,5 prosent hadde systolisk hypertensjon (>140 mmHg) og 19,4 prosent hadde diastolisk hypertensjon (>90 $\mathrm{mmHg}$ ) mens 8,8 prosent hadde glukose $>7,0 \mathrm{mmol} / \mathrm{l}$.

Totalrisikoen for kardiovaskulær død ble kalkulert etter NORRISK-formelen (6), hvor 
alder og risikofaktorer blir håndtert som kontinuerlige variable. Hvor mange av deltakerne som oppfylte kriteriet for videre intervensjon i henhold til de nye nasjonale retningslinjene (7), ble utregnet for tre forskjellige alderstrinn.

Vi identifiserte 19 prosent $\mathrm{i}$ alderen $40-49$ år med Norrisk skår $>1$ prosent (240 deltakere) og 4 prosent i alderen 50-59 år med Norrisk skår $>5$ prosent (226 deltakere), men ingen med totalrisiko over $>10$ prosent i gruppen over 60 år (211 deltakere).

Kun 10,9 prosent (93 deltakere) svarte at de kjente både sitt eget kolesterol og blodtrykk. 60 prosent (514 deltakere) svarte ja på spørsmålet om de var i fysisk aktivitet. Hele 82,8 prosent (totalt 448) av deltakerne anga at de ønsket mer kunnskap om egen helse som motivasjon for deltakelse. 6,5 prosent ønsket hjelp til å forandre levevaner og 11,2 prosent oppga at de ønsket å bidra til at helsepersonell fikk mer kunnskap. Selv om 91,9 prosent (788 deltakere) allerede ved den første kartleggingen anga at de var generelt opptatt av å spise sunt, svarte 63,3 prosent (284 deltakere) på andre spørreskjemaet at undersøkelsen hadde bidratt til at de spiste sunnere enn før.

På spørsmål om de ville anbefale andre å delta på denne type kartlegging, svarte 94,8 prosent (424 deltakere) ja, og mange kom med egne kommentarer til slutt om hva undersøkelsen hadde betydd for dem.

De fleste kommentarer vi mottok var positive. Noen deltakere påpekte at det var lav terskel for å delta og at kartleggingen opplevdes som informativ. Flere fortalte at de var blitt oppmerksomme på at blodtrykket var for høyt og at de hadde konsultert sin lege i forhold til dette og i noen tilfeller startet behandling. Mange deltakere hadde fått råd om å tilstrebe vektreduksjon og fortalte at de hadde gått ned 5-8 kg siden kartleggingen. Blant mer negative kommentarer var at blodtrykksmålingen

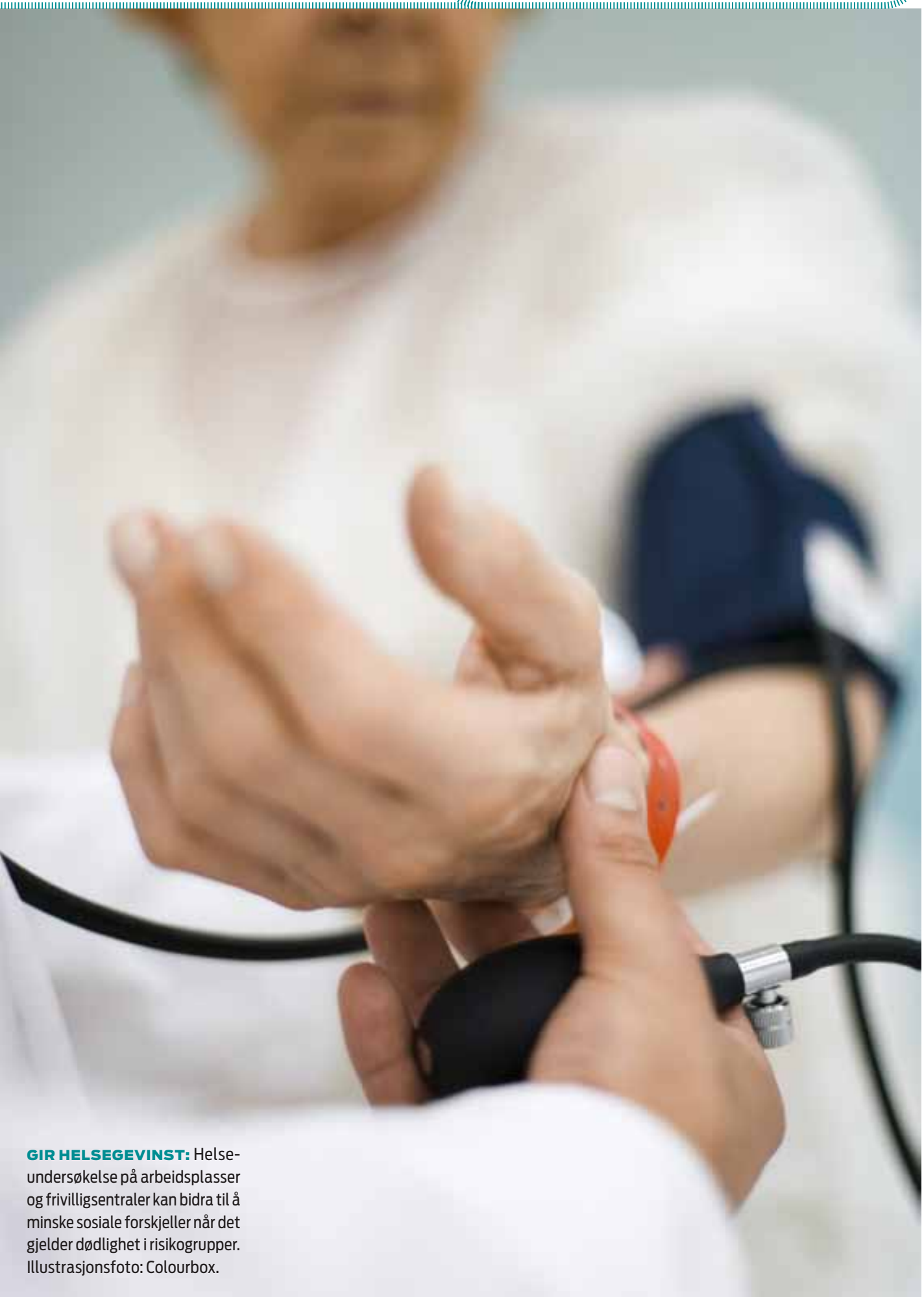

ble opplevd som en stressende prosedyre, mens andre etterlyste kraftigere advarsler.

\section{Diskusjon}

Denne kartleggingsstudien viste at det er mulig å screene personer på risikostatus ved å tilby dette på arbeidsplasser, frivilligsentraler og kjøpesentra ved hjelp av personell fra frivillige organisasjoner. Videre viste studien at blant dem som valgte å delta, var det flere, særlig av de yngre, som hadde risikofaktorer på et nivå som etter Helsedirektoratets nye retningslinjer ville kvalifisere for videre oppfølging med tanke på individuelle primærforebyggende tiltak. Det fremgikk av oppfølgingsspørreskjemaet at en del senere også hadde startet med blodtrykksbehandling. Dette indikerer at denne måten å foreta screening på, kan bidra til å fange opp høyrisikopersoner som ellers ikke ville tatt initiativ til å kartlegge dette hos fastlege, eller ikke var omfattet av bedriftslegeordning eller tilsvarende hvor slike risikofaktorer blir undersøkt.

Fordelingen av deltakerne i forhold til de 
fremmøttes risiko etter NORRISK-tabellene synes noe overraskende. I aldersgruppen 4049 år var andelen med risiko over intervensjonsgrensen størst: 19 prosent hadde risiko $>1$ prosent. Motsatt, fant vi ingen individer med risiko over 10 prosent i aldersgruppen 60-69 år.

I tidligere beregninger fra Tromsøundersøkelsen, fant man at bare 8,4 prosent av menn og $<1$ prosent av kvinner i alder 40-49 år hadde risiko $>1$ prosent, mens hele 36,8 prosent av menn og 6,8 prosent av kvinner hadde risiko >10 prosent i alder 60-69 år (7 s. 116 tabell V. 1). Man må ta i betraktning at våre deltakere ikke er representative for hele po-

\section{«Fastlegesystemet i Norge baserer seg på at individer selv tar kontakt.»}

pulasjonen, og et særlig poeng er at mange av deltakerne i den yngre aldersgruppen var like under 50 år, og mange i den eldste var like over 60 år. Ettersom alder slår sterkt ut på risiko, vil risikoen øke betydelig innenfor hver tiårs aldersgruppe når risikoberegningen gjøres ved hjelp av selve NORRISK-formelen. Grensen for intervensjon derimot, er for enkelhets skyld satt lik for hele aldersintervallet. Dette gjør at det vesentlig er personer i øverste del av aldersintervallene som vil få risiko over tiltaksgrensen. Dette kan ses på som en svakhet ved de nye retningslinjene, og faggruppen bak retningslinjene har også uttalt at man i praksis bør interpolere intervensjonsgrensen når alderen er like over eller under en alderskategori (8).

Det vil si at for personer med alder 49 eller 51 år, bør man operere med en tiltaksgrense på cirka 2,5 prosent, fremfor å anvende tiltaksgrense på 1 prosent på 49- åringer med brå overgang til 5 prosent for 51-åringer. Vår kartleggingsstudie kan illustrere viktigheten av at dette uttrykkes klart i de skriftlige retningslinjene, når disse oppdateres. Problemet unngås imidlertid langt på vei når man bruker risikotabell for risikoberegning, da både estimert risiko og grense for intervensjon blir tilpasset midten av hvert tiårs intervall.

\section{Screening av risikoindivider}

Nytten av å screene befolkningen for kardiovaskulære risikofaktorer er omdiskutert og ufullstendig dokumentert. National Health Services (NHS) i Storbritannia gikk i 2008 i gang med en stor kampanje, «Putting prevention first» (9). De vil i løpet av kampanjen allokere midler til gradvis å innføre nasjonal screening av alle i alderen 40-74 år. Alle over 40 vil få tilbud om en sjekk i forhold til hjerteog karsykdom. NHS har regnet seg frem til at ved å tilby mennesker forebyggende behandling vil de spare 10000 liv årlig. Denne screeningmetoden har senere blitt kritisert for ikke å være kostnadseffektiv (10).

I Norge eksisterte fra slutten av 70-tallet et system for å fange opp personer med høy risiko for hjerte- og karsystem i regi av Statens Helseundersøkelser (SHUS). Denne virksomheten ble lagt ned i 2002, og siden har det ikke vært noe tilbud for å screene befolkningen i forhold til kardiovaskulær risiko. Screening er heller ikke anbefalt i Helsedirektorats nye retningslinjer (7). I disse retningslinjene gir man i stedet anbefalinger om hvilke kliniske situasjoner som kan egne seg for risikovurdering:

, Når en person ber om en vurdering av sin risiko eller av én enkelt risikofaktor.

, Når legen eller pasienten har kjennskap til høyt nivå av én eller flere risikofaktorer.

, Når det foreligger symptomer eller tegn som er forenlig med en risikotilstand, som for eksempel hodepine på bakgrunn av en ubehandlet hypertensjon (høyt blodtrykk). , Når det foreligger kunnskap om tidlig hjerteog karsykdom i familien.

\section{Opp til den enkelte}

Fastlegesystemet i Norge baserer seg på at individer selv tar kontakt. Dermed er ansvaret for å søke helsehjelp i stor grad overlatt til individene, noe som på mange måter er ønskelig. Det eksisterer imidlertid en risiko for at et slikt system bidrar til de sosiale helseforskjellene i Norge. En ny norsk studie viser at til tross for en generell nedgang i dødelighet $\mathrm{i}$ Norge, så økte forskjellen i dødelighet mellom grupper med høy versus de med lavere utdanning i perioden 1960-2000. Studiens forfattere mener at den største årsaken til dette er forskjellen i helserelatert atferd, eller levevaner (11).

Nasjonalforeningen for folkehelsen utførte både i 2004 og 2007 MMI undersøkelser, hvor det kom frem at kun fire av ti kjente til kolesterolnivået sitt. I den aktuelle studien fant vi at bare drøyt 10 prosent kjente både blodtrykket og kolesterolnivået sitt. Dette viser at til tross for mye oppmerksomhet i media om livsstil og kosthold, har mange individer fortsatt begrenset kjennskap til egen risikoprofil.

Et argument mot å screene friske personer for sykdomsrisiko er at dette kan virke belastende på noen og gi økt engstelse for sykdom. Hensikten med spørreskjema nummer to var blant annet å evaluere i hvilken grad deltakerne hadde slik erfaring. Blant dem som responderte var det svært få som opplevde kartleggingen negativt (94 prosent var positive), men den lave svarprosenten (52 prosent) gjør at vi ikke kan utelukke at en viss andel likevel kan ha opplevd det negativt.

\section{Helsepolitiske føringer}

Norske myndigheter har en ærerik historie når det gjelder forebyggende tiltak med Statens tobakksskaderåd og ernæringsråd som viste politisk vilje og handlingskraft på 70-tallet. Gjennom stortingsmelding nr. 16, Resept for et sunnere Norge (2004), Handlingsplanen for økt fysisk aktivitet (2005) og Handlingsplanen for bedre kosthold i befolkningen (2007) er forebygging igjen satt på agendaen i Norge. Bak handlingsplanene står flere departementer samlet og planene legger opp til kraftinnsats og samarbeid på mange nivåer. De frivillige organisasjonene utfordres spesielt av myndighetene til å bidra. I Samhandlingsreformen (St.meld. nr. 47 2008-2009) er det også fokusert på forebygging. Signalene er at dette skal skje så lokalt som mulig, Erfaringen fra vår kartleggingsstudie kan indikere at dette er en måte frivillige organisasjoner kan ta del i forebyggende arbeid på, og hvor en viktig målgruppe for forebyggende tiltak kan nås. Det vil sannsynligvis være hensiktsmessig å utvikle et strukturert samarbeid med fastlegene for senere oppfølging av de personene som får påvist ugunstig risikostatus.

\section{Svakheter ved studien}

Vår studie hadde til hensikt å se i hvilken grad oppsøkende screening lot seg gjennomføre, og i hvilken grad man ville kunne identifisere individer med så høy risiko at forebyggende tiltak bør anbefales. Vi vet imidlertid lite om i hvilken grad våre deltakere var representative for sin aldersgruppe, hva slags sosial profil de fremmøtte hadde, eller om vi klarte å fange opp personer som ellers ikke ville fått kontrollert sin risikostatus. At bare 10 prosent kjente til både kolesterol- og blodtrykksnivået sitt 
er imidlertid en indikasjon på at vi nådde et publikum med mangelfull kjennskap til egen helse eller sykdomsrisiko.

I forhold til tidligere helseundersøkelser fant vi, særlig hos menn, overraskende lavt gjennomsnittskolesterol (median 4,9 mmol/l), men en ganske stor andel av begge kjønn (31 prosent) med høyt systolisk blodtrykk. Sistnevnte må imidlertid ses i forhold til at vår kartlegging i utgangspunktet bare besto av en enkeltmåling, og selv hos dem som ved første måling lå over 140/90, ble det bare gjort en kontrollmåling. Det er derfor sannsynlig at en viss andel av deltakerne som lå over 140 mmHg i systolisk blodtrykk, ville hatt mer normale verdier ved kontroll hos fastlegen.

Vi har ingen sikker forklaring på hvorfor gjennomsnittlig kolesterol lå lavere enn ved tidligere helseundersøkelser, der man for eksempel i data fra helseundersøkelser i Oslo i 2003 fant totalkolesterol rundt $5,7 \mathrm{mmol} / \mathrm{l}$ for aldersgruppen 40-45 år (12). Selve tørrkjemimetodikken kan ha noen unøyaktigheter sammenliknet med vanlig biokjemiske analyser, men dette synes ikke nok til å forklare en forskjell på cirka 0,5-0,7 mmol i totalkolesterol. Forskjellen kan mer trolig bero på at utvalget er selektert på en annen måte enn ved tidligere helseundersøkelser, men man kan heller ikke utelukke at det har skjedd en ytterligere nedgang i befolkningens lipidnivå i løpet av de siste sju årene.

En videre svakhet ved studien er den lave svarprosenten ved spørreskjema 2. De data vi har er derfor ikke nødvendigvis representative for de som ikke responderte, og totalt sett kan kartleggingen ha blitt opplevd mindre positivt enn tallene våre tilsier.

\section{Oppsummering}

Med dette kartleggingsprogrammet fikk vi vist at det er mulig å tilby et lavterskeltilbud på arbeidsplasser og på offentlige samlingsplasser (kjøpesentre/frivilligsentraler) hvor man vil kunne identifisere et ikke ubetydelig antall høyrisikoindivider. Vi mener også at erfarne hjertesykepleiere vil kunne ivareta denne type screening og rådgivning om levevaner vil på en god måte av. Nasjonalforeningen for folkehelsen er avhengig av god profilering og anerkjennelse for sitt arbeid og dette prosjektet bidro til at organisasjonen fikk vist seg som en aktør på den forebyggende arenaen. Vi ble tatt godt imot på de arbeidsplassene vi besøkte og det var stor pågang fra de ansatte. Der hvor vi ikke rakk å undersøke alle, ble vi bedt om å komme tilbake grunnet stor etterspørsel. Dessverre tillot ikke tidsrammen og prosjektfinansieringen at vi fikk gjennomført dette, men vi opplevde en slik respons som inspirerende for senere kampanjer. IIII

Prosjektet er finansiert med midler fra EkstraStiftelsen Helse og Rehabilitering.

\section{LITTERATUR}

WHO Technical Report Series 2003, Diet, nutrition and the prevention of chronic diseases (5. 43).

Holme I, Tonstad S. Risikofaktorer og dødelighet - oppfølging av Osloundersøkelsen fra 1972-73. Tidsskr Nor Legeforen 2011;131:456-60

3edersen JI, Tverdal A, Kirkhus B. Kostendringer og dødelighetsutvikling av hierte- og karsykdommer i Norge. Tidsskr. Nor Legeforening 2004: 124: $1532-6$

4. Thor Aspelund et al. Analysing the large decline in coronary heart diseas mortality in the Icelandic population aged $25-74$ between the years 198 and 2006. PLoS One. 2010 Nov 12;5 (11): el3957

5. Folkehelserapporten 2010. Helsetilstanden i Norge. Folkehelseinstituttet rapport 2010:2

6. Selmer R, Lindman AS, Tverdal A, Pedersen JI, Njølstad I, Veierød MB. Modell for estimering av kardiovaskulær risiko i Norge. Tidsskr. Nor Legeforening 2008; 128: 286-90

7. Nasjonale Retningsinjer for individuell primærforebygging av hjerte- 08 karsykdommer, Helsedirektoratet mai 2009

8. Norheim OF, Gjelsvik B, Klemsdal TO et al. Norway's new principles for primary prevention of cardiovascular disease: age differentiated risk thresholds. BMJ 2011; 343: 3626 doi: 10.1136

9. Putting prevention first. Vascular checks: Risk assessment and manage ment.

Department of health, NHS 2008

10. Chamnan P, Simmons RK, Khaw KT, Wareham NJ, Griffin SJ. Estimating the population impact of screening strategies for identifying and treating people at high risk of cardiovascular disease: modelling study. BMJ. 2010 Apr 23;340:c1693. doi: 10.1136/bmj.c1693.

11. Strand BH et al. Educational inequalities in mortality over four decades in Norway: prospetive study of middle aged men and women followed

12. Jenum AK Graff-Iversen S, Selmer RM, Søgaard AJ. Risikofaktorer for hjerte- og karsykdom og diabetes gjennom 30 år. Tidsskr Nor Legeforening 2007; 127:2532-6.

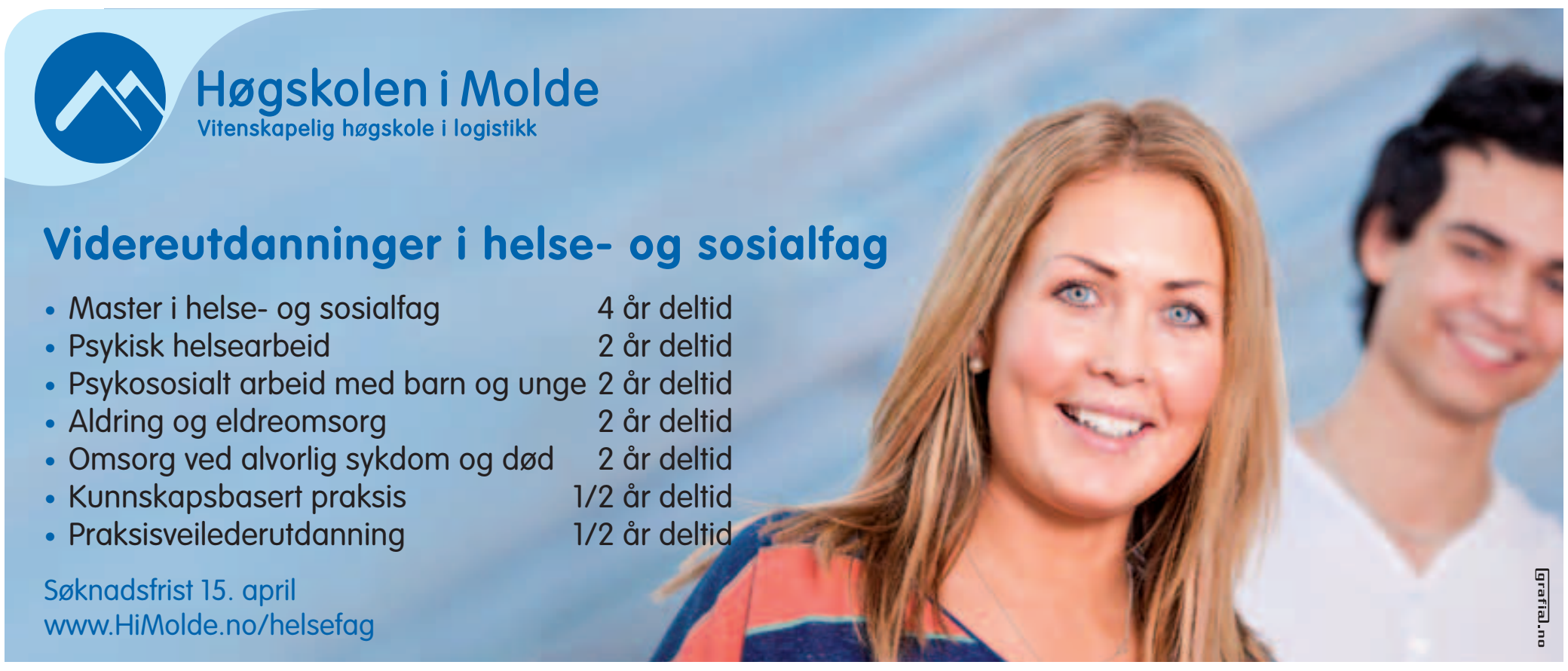

